\title{
Isolation and Screening of Novel Microorganisms from the Minor Millets
}

\author{
T. Boobalan ${ }^{1}$, R. Thamizh Vendan ${ }^{1 *}$, R. Subhashini ${ }^{1}$, P. Kannan ${ }^{2}$ and G. Srinivasan ${ }^{3}$ \\ ${ }^{1}$ Department of Agricultural Microbiology, Agricultural College and Research Institute, Tamil \\ Nadu Agricultural University, Madurai, India \\ ${ }^{2}$ Department of Soils and Environment, Agricultural College and Research Institute, Tamil \\ Nadu Agricultural University, Madurai, India \\ ${ }^{3}$ Regional research station, Aruppukottai, India \\ *Corresponding author
}

\section{A B S T R A C T}

\section{Keywords}

Minor millets, novel microbes, Nitrogen fixer, Phosphorus and Potassium solubilizer

Article Info

\section{Accepted:}

12 December 2020

Available Online:

10 January 2021
Minor millets are drought-resistant crops, normally grown under rainfed conditions. Reducing the application of chemical fertilizers will reduce the cost of cultivation drastically. This study aimed to isolate and screening the novel microorganisms from the rhizosphere soil of the minor millets for supplementing the major plant nutrients. Totally 18 different isolates were isolated from the rhizosphere of minor millets. Out of which, 12 isolates were screened based on their performance. Among them, isolates D6, D5 and D1 were exhibited better performance in ARA activity $\left(840 \pm 14.3 \mathrm{p} \mathrm{mol} \mathrm{mg}^{-1} \mathrm{~h}\right)$, phosphorous solubilization $\left(3.08 \pm 0.005 \mathrm{~cm}^{2}\right)$, and potassium solubilization $\left(6.59 \pm 0.027 \mathrm{~cm}^{2}\right)$ respectively. The isolates D6, D5, and D1 were found to be promising in supplying the major nutrients to the crops and could be used for further research to develop suitable inoculants for millets.

\section{Introduction}

Millets are the world's most important ancient domestic crops. Before the popularity of rice and wheat, millets are the stable foods in the semiarid regions of East Asia and even in the entire Euro-Asian continent (Weber et al., 2008). Millets are referred to as 'Nutricereals' (Ministry of Agriculture, India. 2018), because of the nutrition quality and its stover is an important animal feed. Millets can withstand severe biotic and abiotic stress with fewer inputs (Padulosi et al., 2015). In general, millets do not require any external inputs, but to increase the productivity of the minor millets, we should supply the major nutrients in the form of fertilizers. Instead of regular usage of chemical fertilizers, we can supplement nutrients through the application of biofertilizers. Biofertilizers are low cost, effective, and renewable source of plant nutrients (Borasteet al., 2009). Biofertilizers can supplement $25 \%$ of the crop fertilizer requirement (Chauhan et al., 2015 and Rekha et al., 2018). Thilagar et al., 2016 reported as application selective microorganisms reduce 
chemical fertilizer usage by up to $50 \%$.To supplement the chemical fertilizers and to supply the major nutrients to these crops, it was planned to isolate and screen the novel microorganisms from minor millets grown in various places of Tamil Nadu.

\section{Materials and Methods}

\section{Soil sample collection}

Totally 12 rhizosphere soil samples were collected from different locations of Tamil Nadu, India by carefully uprooting the root system of the minor millets viz., Barnyard millet, pearl millet, and finger millet. Soil samples were stored at $4^{\circ} \mathrm{C}$ for future use.

\section{Isolation from the rhizosphere soil}

For isolation of novel microbes, the sievedsoil plate method (Jensen et al., 1960) was used. Soil particles were evenly distributed over the previously prepared Nutrient agar media and incubated at $30^{\circ} \mathrm{C}$ for $48 \mathrm{hr}$. Those isolated cultures were purified and stored in agar slants for future use. Among 18 different isolates were screened based on their morphological and biochemical characteristics and they were named according to their place of isolation (Boothakudi, Madurai:B; Paramathivelur:P; Dharmapuri:D).

\section{Characterization and screening}

For characterization, biochemical tests were performed. ARA activity was used for screening the $\mathrm{N}$ fixing microorganisms. Pikovaskaya's media and Aleksandrov's media were used for screening the phosphate and potassium solubilizing microorganisms.

\section{Nitrogen-fixing efficiency}

Before testing the ARA activity of the isolates, they were grown in NFB media
Dobereiner., (1995) and observed for the colour changes (green into blue colour) which indicate the growth of the isolates in the nitrogen-free media.

Acetylene reduction assay (ARA)was used to determine the nitrogenase activity of the isolates Hardy et al., (1968). Each bacterial isolate was grown in a $20-\mathrm{ml}$ test tube containing $10 \mathrm{ml}$ of nitrogen-free semi-solid medium for $72 \mathrm{~h}$ at $30^{\circ} \mathrm{C}$. Each test tube was sealed with a rubber stopper, and $1 \mathrm{ml}$ of acetylene gas was replaced to the air in the headspace $(10 \mathrm{ml})$. The test tubes were incubated at $30^{\circ} \mathrm{C}$ for $24 \mathrm{~h}$. One $\mathrm{ml}$ of each gas sample from the headspace was assayed for ethylene production by gas chromatograph (Varian GC (CP-3800)) equipped with a hydrogen flame ionization detector (FID) and a Porapack N column. Nitrogenase activity was calculated as nmol of ethylene per tube per hr.

\section{Screening for $\quad P \quad$ solubilizing microorganisms}

For screening of phosphorus solubilizing microorganisms, Pikovaskaya's media was used. For that $24 \mathrm{hr}$ old cultures were inoculated in the Pikovaskaya's agar plates supplemented with $0.5 \%$ tricalcium phosphate by using spot inoculation technique and incubated at $28 \pm 1^{\circ} \mathrm{C}$ for 4 days (Gaind, 2013). The area of phosphate solubilization zone formation $\left(\mathrm{cm}^{2}\right)$ was recorded after 4 days of incubation (Pikovskaya., 1948).

\section{Screening for $\quad \mathrm{K}$ solubilizing microorganisms}

Totally three different Aleksandrov's media was prepared for assessing the $\mathrm{K}$ solubilization. Plates of Aleksandrov's media and modified Aleksandrov's media (Saha et al., 2016) were prepared by using $\mathrm{KH}_{2} \mathrm{PO}_{4}$ and $\mathrm{K}_{2} \mathrm{HPO}_{4}$. Then $48 \mathrm{hr}$ old cultures (from 
NA broth) are inoculated in the plates and incubated at $28 \pm 2{ }^{\circ} \mathrm{C}$ for 3 days. The area of the solubilization zone formed around the colonies after the incubation period was measured (Aleksandrov et al., 1967).

The area of the solubilization zone was expressed in $\left(\mathrm{cm}^{2}\right)$, calculated by using the area of a circle formula.

$A=\pi r^{2}$

Where,

A - Area, $\square$ - 3.14, and r - Radius.

\section{Statistical analysis}

The experiment was conducted in a completely randomized block design. The results presented are the mean of three replicates. Sample variability was estimated by the standard deviation of the mean. Analysis of variance on the data at CD 5\%.

\section{Results and Discussion}

Totally 18 different isolates were isolated from the rhizosphere soil of the minor millets and characterized based on the morphology and biochemical tests. All the isolates were rod-shaped and half of the isolates were grampositive, the remaining isolates were gramnegative (table:1).Isolates B1, B3, B7, P2, D2, D3-I, D4-II, and D5 were positive for citrate utilization test, they produced blue colour in Simmon's citrate agar. Among the 18 isolates, 12 isolates were positively performed in the above screening methods.

Table.1 Morphological and biochemical characterization of rhizosphere isolates of minor millets

\begin{tabular}{|c|c|c|c|c|c|c|c|c|}
\hline Isolates & $\begin{array}{l}\text { Gram } \\
\text { reaction }\end{array}$ & $\begin{array}{l}\text { Colony Colour and } \\
\text { morphology }\end{array}$ & $\begin{array}{l}\text { Catalase } \\
\text { test }\end{array}$ & $\begin{array}{l}\text { MR } \\
\text { test }\end{array}$ & $\begin{array}{l}\mathrm{VP} \\
\text { test }\end{array}$ & $\begin{array}{c}\text { Citrate } \\
\text { utilization test }\end{array}$ & $\begin{array}{c}\text { Starch } \\
\text { hydrolysis }\end{array}$ & $\begin{array}{l}\text { Cellulase } \\
\text { production }\end{array}$ \\
\hline B1 & - & Raised white & + & - & + & + & - & - \\
\hline B3 & + & Raised Dull yellow & + & + & + & + & - & - \\
\hline B4 & + & Transparent slimy & + & - & - & - & - & - \\
\hline B7 & + & Dull brown & + & - & + & $(+)$ & - & - \\
\hline B8 & - & $\begin{array}{c}\text { Translucent and uneven } \\
\text { edges }\end{array}$ & - & + & + & - & - & - \\
\hline B9 & - & $\begin{array}{c}\text { Brown colonies with white } \\
\text { edges }\end{array}$ & - & - & - & - & - & - \\
\hline $\mathbf{P 1}$ & + & White slimy & + & - & + & - & + & + \\
\hline $\mathbf{P 2}$ & - & Raised white slimy & + & - & + & + & - & - \\
\hline P3 & + & White slimy & + & - & - & - & - & - \\
\hline D1 & - & $\begin{array}{l}\text { Dull yellow smooth } \\
\text { colonies }\end{array}$ & + & - & + & - & - & - \\
\hline D2 & + & Flat dull white & + & - & + & + & - & - \\
\hline D3-I & - & White slimy & + & - & + & + & - & - \\
\hline D4-II & + & Dull yellow, translucent & + & - & - & $(+)$ & - & $(+)$ \\
\hline D5 & + & Flat white smooth & + & - & + & $(+)$ & + & + \\
\hline D6 & + & $\begin{array}{l}\text { White slimy with uneven } \\
\text { edges }\end{array}$ & - & - & + & - & - & - \\
\hline D8 & - & $\begin{array}{l}\text { Slimy white with yellow } \\
\text { spots }\end{array}$ & + & + & + & - & - & - \\
\hline D9 & - & Dull brown colour & + & - & + & - & - & - \\
\hline D12 & - & Slimy white & + & - & + & - & - & - \\
\hline
\end{tabular}


Table.2 Qualitative assay of $\mathrm{P}$ and K solubilization for the isolates of minor millets

\begin{tabular}{|c|c|c|c|c|}
\hline \multirow[t]{2}{*}{ Isolates } & \multirow{2}{*}{$\begin{array}{c}\text { Phosphorus } \\
\text { solubilization zone } \\
\text { in } \mathrm{cm}^{2}\end{array}$} & \multicolumn{3}{|c|}{ Potassium solubilization zone in $\mathrm{cm}^{2}$} \\
\hline & & $\begin{array}{l}\text { Potassium } \\
\text { aluminosilicate }\end{array}$ & $\mathrm{KH}_{2} \mathrm{PO}_{4}$ & $\mathrm{~K}_{2} \mathrm{HPO}_{4}$ \\
\hline B1 & - & $5.2 \pm 0.075^{\mathrm{b}}$ & $2.07 \pm 0.034^{c}$ & $1.81 \pm 0.034^{\mathrm{c}}$ \\
\hline B3 & - & - & $1.51 \pm 0.014^{\mathrm{d}}$ & - \\
\hline $\mathbf{P 2}$ & $2.5 \pm 0.008^{b}$ & $5.27 \pm 0.031^{\mathrm{b}}$ & $3.2 \pm 0.019^{b}$ & $2.05 \pm 0.030^{\mathrm{b}}$ \\
\hline P3 & $1.32 \pm 0.003^{\mathrm{c}}$ & $3.2 \pm 0.014^{\mathrm{d}}$ & $1.45 \pm 0.026^{\mathrm{d}}$ & - \\
\hline D1 & - & $6.59 \pm 0.027^{\mathrm{a}}$ & $5.53 \pm 0.115^{\mathrm{a}}$ & $4.59 \pm 0.062^{\mathrm{a}}$ \\
\hline D3-I & - & $1.22 \pm 0.012^{\mathrm{e}}$ & $1.32 \pm 0.011^{\mathrm{e}}$ & - \\
\hline D5 & $3.08 \pm 0.005^{\mathrm{a}}$ & - & - & - \\
\hline D6 & - & $3.98 \pm 0.074^{\mathrm{c}}$ & - & $1.06 \pm 0.020^{\mathrm{d}}$ \\
\hline D8 & $0.44 \pm 0.005^{\mathrm{d}}$ & - & - & - \\
\hline Grand mean & 0.816 & 2.828 & 1.676 & 1.057 \\
\hline SEd & 0.006 & 0.066 & 0.073 & 0.046 \\
\hline CD (0.05) & 0.014 & 0.140 & 0.152 & 0.097 \\
\hline
\end{tabular}

Fig.1 Estimation of Acetylene reduction activity (ARA) for the isolates of minor millets

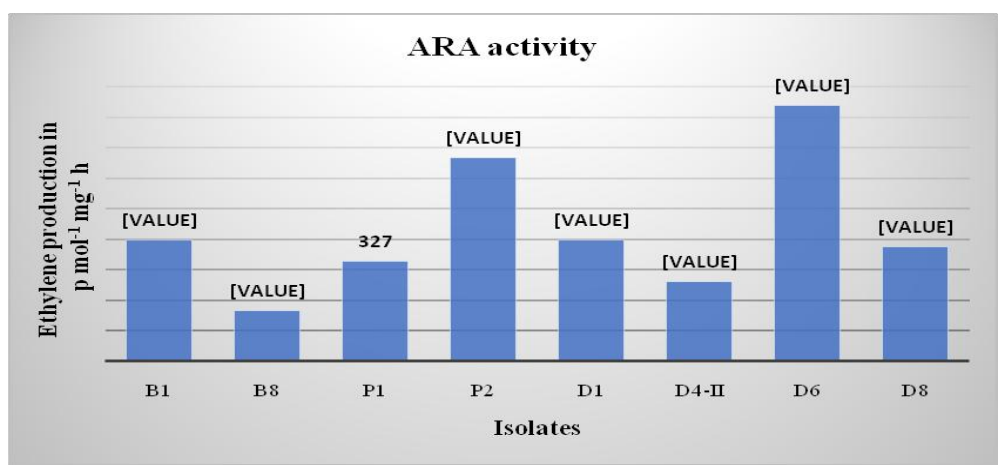

Plate.1 Growth of Nitrogen-fixing isolates in Nitrogen free broth and solubilization zone formation by the $\mathrm{P}$ and $\mathrm{K}$ solubilizing isolates

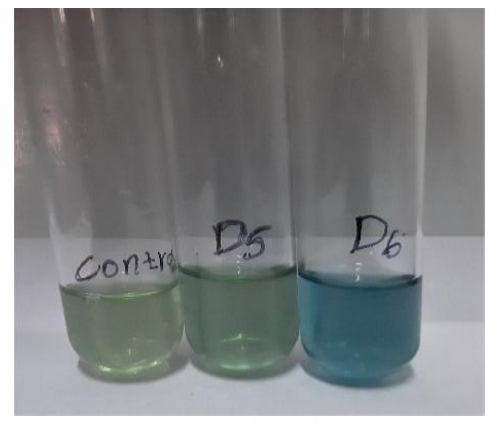

NFB broth

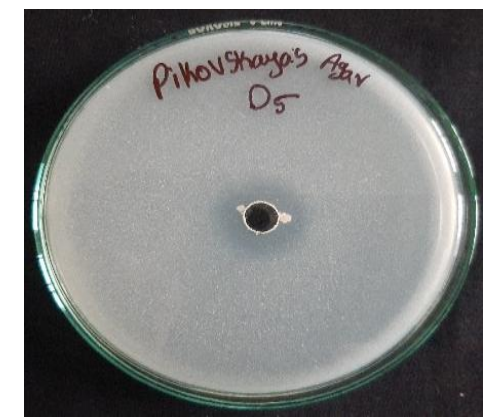

Phosphorus solubilization

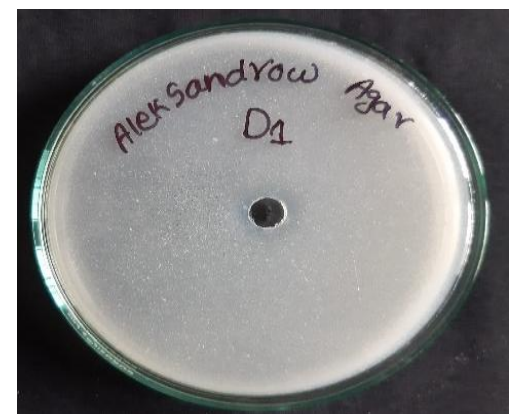

Potassium solubilization 
ARA activity is used to indirectly identify the presence of nitrogenase enzyme which is responsible for the fixation of atmospheric nitrogen. In this study, among the 18 isolates, 8 cultures were showed positive for nitrogen fixation.

Based on the obtained results, the bacterial isolate D6 exhibited higher nitrogen-fixing efficiency $(840 \pm 14.3 \mathrm{nmol}$ of ethylene produced $\mathrm{h}^{-1} \mathrm{mg}^{-1}$ protein) (Fig:1) followed by P2 $\left(667.2 \pm 9.6 \mathrm{p} \mathrm{mol}^{-1} \mathrm{mg}^{-1} \mathrm{~h}\right)$ and B1(397.8 $\left.\pm 6.7 \mathrm{p} \mathrm{mol}^{-1} \mathrm{mg}^{-1} \mathrm{~h}\right)$.

Isolate B8 exhibited the least nitrogen-fixing efficiency $\left(165.6 \pm 0.3 \mathrm{p} \mathrm{mol}{ }^{-1} \mathrm{mg}^{-1} \mathrm{~h}\right)$ compared to the other isolates. Similarly, Tiwari et al.,(2003)isolated and characterized diazotrophs by using ARA activity, from the rhizosphere soil of the pearl millet (Pennisetum glaucum). Isolate D6 changed the NFB broth colour, green into blue (Plate:1).

The ability of the Phosphorus solubilization was estimated by Pikovaskaya's media supplemented with $0.5 \%$ tricalcium phosphate. From the results, the isolateD5 formed the higher clear zone area, 3.08 \pm 0.005 $\mathrm{cm}^{2}$ (Table:2) around the colonies followed by $\mathrm{P} 2$ and $\mathrm{P} 3$, which formed $2.5 \pm 0.008 \mathrm{~cm}^{2}$ and $1.32 \pm 0.003 \mathrm{~cm}^{2}$ solubilization zones respectively.

Among the isolates, D8 forms the least solubilization zone $\left(0.44 \pm 0.005 \quad \mathrm{~cm}^{2}\right)$ (Plate:1).Similar studies were done in foxtail millet (Setaria italica L.) by Kouret al., (2020) and reported as the application of $\mathrm{P}$ solubilizing microorganisms useful for stress environmental conditions.

In the case of screening for Potassium releasing ability,isolateD1performed well(Plate:1). Isolate D1 solubilized all three different potassium sources, viz., Potassium alumina silicate $\left(6.59 \pm 0.027 \mathrm{~cm}^{2}\right), \quad \mathrm{KH}_{2} \mathrm{PO}_{4}$ $\left(5.53 \pm 0.115 \mathrm{~cm}^{2}\right)$, and $\mathrm{K}_{2} \mathrm{HPO}_{4}(4.59 \pm 0.062$ $\mathrm{cm}^{2}$ ) (Table.2). Previous study revealed that rhizosphere isolates (Bacillus sp) from the common bean, solubilized the potassium sources in the Aleksandrov's medium (Kumar et al., 2012).

Among the isolates, B1, P2, and D1 solubilized the three sources of $\mathrm{K}$ which were supplemented with Aleksandrov's medium. Isolates D5 and P1 both can hydrolysis the starch and the cellulose (Table:1), which proved the production of amylase and cellulase enzymes. Similar results were also reported by Onah and Tseea, (2003).

From this study, it was concluded that isolate D6 exhibited higher nitrogen-fixing efficiency, isolate D5 showed better solubilization in phosphorous, and D1 solubilized all the three sources of potassium (Potassium aluminosilicate, $\mathrm{KH}_{2} \mathrm{PO}_{4}$, and $\mathrm{K}_{2} \mathrm{HPO}_{4}$ ).

The isolates D6, D5, and D1 were found to be promising in supplying the major nutrients to the crops and could be used for further research to develop suitable inoculants for millets.

\section{References}

Aleksandrov, V. G., R. N. Blagodyr, and I. P. Ilev. Liberation of phosphoric acid from apatite by silicate bacteria. Mikrobiol Z 29, no. 11 (1967): 1-1.

Boraste, A., K. K. Vamsi, A. Jhadav, Y. Khairnar, N. Gupta, S. Trivedi, P. Patil et al., Biofertilizers: A novel tool for agriculture. International Journal of Microbiology Research 1, no. 2 (2009): 23.

Chauhan, Hemlata, and D. Joseph Bagyaraj. Inoculation with selected microbial consortia not only enhances growth and 
yield of French bean but also reduces fertilizer application under field condition. Scientia Horticulturae 197 (2015): 441-446.

Dobereiner, J. Isolation and identification of aerobic nitrogen-fixing bacteria from soil and plants. In Methods in Applied Soil Microbiology and Biochemistry, eds. Alef, K., and Nannipieri, P. London: Academic Press. pp 134 (1995): 141.

Gaind, Sunita. Pseudomonas striata for improving phosphorus availability in soil under Pearl Millet cultivation. Journal of Crop Improvement 27, no. 3 (2013): 255271.

Hardy, R_ WF, R. D. Holsten, E. K. Jackson, and R. C. Burns. The acetylene-ethylene assay for N2 fixation: laboratory and field evaluation. Plant physiology 43, no. 8 (1968): 1185-1207.

Jensen, H. L., Erik J. Petersen, P. K. De, and Roma Bhattacharya. A new nitrogenfixing bacterium: Derxia gummosa nov. gen. nov. spec. Archivfürmi krobiologie 36, no. 2 (1960): 182-195.

Kour, Divjot, Kusam Lata Rana, Ajar Nath Yadav, Imran Sheikh, Vinod Kumar, Harcharan Singh Dhaliwal, and Anil Kumar Saxena. Amelioration of drought stress in Foxtail millet (Setaria italica L.) by P-solubilizing drought-tolerant microbes with multifarious plant growth promoting attributes. Environmental Sustainability (2020): 1-12.

Kumar, Pankaj, R. C. Dubey, and D. K. Maheshwari. Bacillus strains isolated from rhizosphere showed plant growth promoting and antagonistic activity against phytopathogens. Microbiological research 167, no. 8 (2012): 493-499.

Onah, Ejembi, and TseeaShambe. Degradation of starch and carboxymethylcellulose (CMC) by extracellular enzymes from four bacteria species. In abstracts of papers of the
American Chemical Society, vol. 225, pp. U275-U275. 1155 16th st, NW, Washington, DC 20036 USA: Amer Chemical SOC, 2003.

Padulosi, Stefano, Bhag Mal, Oliver I. King, and Elisabetta Gotor. Minor millets as a central element for sustainably enhanced incomes, empowerment, and nutrition in rural India. Sustainability 7, no. 7 (2015): 8904-8933.

Pikovskaya, RI. 1948. Mobilization of phosphorus in soil in connection with vital activity of some microbial species. Mikrobiologiya 17:362-370.

Rekha, D. Lasya Mohana, R. Lakshmipathy, and A. Vijaya Gopal. Effect of Microbial Consortium and Organic Manure on Growth and Nutrients Uptake in Pearl Millet (Pennisetum glaucum L.). Int. J. Curr. Microbiol. App. Sci 7, no. 6 (2018): 2256-2261.

Saha, Madhumonti, Bihari Ram Maurya, Vijay Singh Meena, Indra Bahadur, and Ashok Kumar. Identification and characterization of potassium solubilizing bacteria (KSB) from IndoGangetic Plains of India. Biocatalysis and agricultural biotechnology 7 (2016): 202-209.

Thilagar, G., D. J. Bagyaraj, and M. S. Rao. Selected microbial consortia developed for chilly reduces application of chemical fertilizers by $50 \%$ under field conditions. Scientia Horticulturae 198 (2016): 27-35.

Tiwari, Mala, Shashi Paroda, and K. R. Dadarwal. Associative diazotrophs of pearl millet (Pennisetum glaucum) from semi arid region-Isolation and characterization. (2003).

Weber, Steven A., and Dorian Q. Fuller. Millets and their role in early agriculture. Pragdhara 18, no. 69 (2008): e90. 


\section{How to cite this article:}

Boobalan, T., R. Thamizh Vendan, R. Subhashini, P. Kannan and Srinivasan, G. 2021. Isolation and Screening of Novel Microorganisms from the Minor Millets. Int.J.Curr.Microbiol.App.Sci. 10(01): 1025-1031. doi: https://doi.org/10.20546/ijcmas.2021.1001.124 